\title{
The Influence of Psychological Capital and Workplace Well-Being on Work Engagement of Bank Employees
}

\author{
Osa Dyahayu Kalmudojati
}

Gunadarma University, Faculty of Psychology, Jl. TB Simatupang Pasar Minggu, Jakarta Selatan, Indonesia

\begin{abstract}
The challenge comes from increasingly fierce business competition and increasingly varied customer demands for products and services. Therefore, apart from capital and technology, banks also need the support of reliable human resources. The purpose of this study was to determine empirically whether there was any influence between psychological capital and workplace well-being on the work engagement of employees at the Bank. This study involved 134 respondents. The results obtained indicate that the empirical model obtained is in accordance with the theoretical model that was built. The variables of psychological capital and workplace wellbeing together influence work attachment to Bank employees.
\end{abstract}

Keyword: Psychological Capital, Workplace Well-Being, Work Engagement

\section{INTRODUCTION}

Organization is defined as a social unit consisting of two or more people and functions relatively continuously to achieve common goals or objectives (Robbins, 2006) ${ }^{1}$. One of the well-known forms of organization is a bank. According to Supomo (LPPI, 2011) ${ }^{2}$, the Indonesian banking industry has shown its progress in supporting the national economy. However, in the course of building a strong banking industry, Indonesian banks still face various challenges.

These challenges stem from, among others, increasingly fierce business competition and increasingly varied customer demands for products and services. For this reason, aside from capital and technology, banks also need the support of reliable human resources. Based on these needs, companies need energetic and dedicated employees, namely employees who have work engagement in carrying out their work (Schaufeli, 2006) ${ }^{3}$. Based on the results of a research survey conducted by Towers Watson in a survey entitled Global Workforce Study (GWS) involving 1,005 employees in Indonesia, the results are very sad because the survey results show that almost two-thirds of employees in Indonesia do not have a strong relationship with the company.

Even more worrying is that around $38 \%$ of unattached employees are likely to leave their jobs within 2 years. In contrast, only $21 \%$ of engaged employees would like to leave their current company within the same period (Watson, 2017) ${ }^{4}$. There is also a case in Indonesia, the phenomenon of turnover intentions from the results of the 2014 Price Water House Coopers (PwC) Indonesia survey of the banking sector in Indonesia shows that the turnover rate in this sector reaches $15 \%$. The survey conducted by $\mathrm{PwC}$ shows that human resources in the banking sector often move between companies. The survey shows that $54 \%$ of respondents moved for better benefits, $37 \%$ of respondents said they were looking for other workplaces for career advancement, $4 \%$ of respondents changed banks because they wanted a challenge, and $4 \%$ changed offices because they were not satisfied with their boss's leadership style. 
The results of the 2015 salary survey conducted by Mercer Talent Consulting \& Information Solution showed that the talent turnover rate from all sectors was still high, namely $8.4 \%$, the highest was in the banking sector at $16 \%$. The biggest trigger for employees to move jobs is to see retention, remuneration and a clear career path in the company. The phenomenon can be said that employee turnover can be interpreted as a lack of work attachment

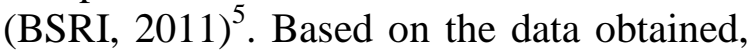
employee attachment to a company is very important. According to Schaufeli and Bakker (2010) ${ }^{6}$ engagement has two terms, namely work engagement and employee engagement which can usually be used interchangeably. The term work engagement refers to the relationship between employees and their jobs, while employee engagement refers to the relationship between employees and their organizations.

Work engagement is an aspect that includes positive emotions, full involvement in doing work and is characterized by three main dimensions, namely vigor, dedication, and absorption. If employees have high engagement, the company will get many benefits such as improving organizational culture, increasing employee and consumer loyalty, high sales and profits (Attridge, 2009) ${ }^{7}$. Previous studies have found some evidence that engaged employees will help restore stability and profitability to the organization after being hit by difficulties. In addition, engaged employees will work actively and try to reach and think about doing things better (Robertson, 2008) ${ }^{8}$.

Simbula and Gugliemi (2002) ${ }^{9}$ state that previous research has shown that work engagement is positively related to health, attitudes and behavior. Like Handayani's $(2016)^{10}$ research, the main results of this study show that there is a significant positive relationship between work engagement and organizational citizenship behavior in contract employees. Employees who have a high level of work engagement will show their best performance, this is because these employees enjoy the work they do (Schaufeli and Bakker, 2010). But attachments do not just appear, there are many things that encourage the emergence of an employee's sense of attachment to the company or institution. One of them is psychological capital (psychological capital). An individual psychological capacity that develops with the characteristics of self-efficacy, optimism, hope and resilience.

Psychological capital is the psychological state of a positive individual characterized by having the confidence (self-efficacy) to take and put in the effort necessary to succeed in challenging tasks, make positive attributions (optimism) about current and future successes, diligently achieve goals and if needed focus on achieving goals (hope) to succeed, and when hit by problems and difficulties it will survive and rise again and even get out of the safe zone (resilience) to achieve success (Luthans, Youssef and Avolio, 2007) ${ }^{11}$. Evidenced by research conducted by Mujiasih and Ratnaningsih (2013) ${ }^{12}$ shows that the correlation between psychological capital and work engagement is positive, which means that the higher the psychological capital, the higher the work engagement. This applies to the contrary, the lower psychological capital, the lower the work engagement.

Not only that, the wellbeing obtained by employees from work related to the feelings of employees in general (core affect), intrinsic value and work (work values) known as workplace well-being (WWB) also encourages a sense of attachment (Page, 2005) ${ }^{13}$. Workplace wellbeing (WWB) is important to study because WWB can be a major contributor to improving employee performance and fostering a sense of work engagement (Schmidt, 2004) $^{14}$.

Workplace well-being is the sense of well-being that employees get from their work, which is related to feelings of comfortable and uncomfortable mixing, as well as the passion that affects their 
activities. This is in line with research conducted by Sari $(2015)^{15}$ proving that there is a significant positive relationship between workplace well-being and employee engagement on administrative staff at Satya Wacana Christian University, Salatiga. This means that the higher the workplace well-being, the higher the employee engagement.

The results of previous research were also conducted by Kurniadewi $(2016)^{16}$ which proved that psychological capital and workplace well-being were proven to have an effect on employee work engagement. However, psychological capital is not a significant predictor of employee work engagement.

In this study, the authors conducted research on standard employees (staff) in each field, where employees have worked for at least 2 (two) years, permanent employees (staff) or not interns. Employees are always faced with contributing to the success of the organization on an ongoing basis. Disengagement will arise if the wages received by employees are not in accordance with employee expectations, seen from the performance that has been given so far. Based on the description above, the researcher is interested in examining whether there is an influence between psychological capital and workplace well-being on work engagement among staff level employees at the Bank.

In this study, the formulated hypotheses are:

H1: There is a significant positive effect of psychological capital and workplace wellbeing on employee work engagement.

H2: There is a significant positive psychological capital effect on employee work engagement.

H3: There is a significant positive effect of workplace well-being on employee work engagement.

\section{MATERIALS AND METHODS Research subject}

This study involved 134 bank employees as participants. Participants in this study are standard employees (staff) in each field or unit, all research participants are employees who have worked for at least 1 (one) year, have the status of permanent employees (staff) or are not apprentices, have a minimum education of D3, and participants in this study have a minimum age range of 20 years and a maximum age of 56 years (not yet retired). Based on this number, 93 of them were women, and the remaining 41 were male participants.

\section{Research variable}

The independent variables of this study are psychological capital $\left(\mathrm{X}_{1}\right)$, workplace wellbeing $\left(\mathrm{X}_{2}\right)$, and the dependent variable is work attachment (Y).

The work engagement scale is measured using the UWES (Utrecht Work Engagement Scale) developed by Schaufeli and Bakker $(2004)^{17}$, which consists of 3 aspects and the scale has 17 items. The Vigor aspect, an example of the item "at work, I feel full of energy". Dedication aspect, for example the item "I am enthusiastic about my work". Absorption aspect, for example the item "time runs very fast when I work". This scale, after going through the calculation of the item discrimination power, there are no items that are dropped. The number of items that exist is 17 items with a reliability of 0.753 .

The psychological capital scale is measured using the Psychological Capital Questionnaire (PCQ) from Luthans, Avolio and Avey $(2017)^{18}$, which consists of 4 characteristics, and this scale has 12 items. Self-efficacy, for example the item "I feel confident analyzing long-term problems to find a solution". Hope (hope), an example of the item "if I have to find myself at work, I can think of many ways to get out of it". Resilience, an example of the item "when I have a setback at work, I find it difficult to recover, keep going". Optimism, an example of the item "when things are uncertain for me at work, I usually hope for the best". This scale, after going through the calculation of the item discrimination power, there are no items that are lost. The 
Osa Dyahayu Kalmudojati. The influence of psychological capital and workplace well-being on work engagement of bank employees.

number of items that exist is 12 items with a reliability of 0.933 .

The scale of workplace wellbeing uses the Workplace Wellbeing Questionnaire (WWQ) from Page (2005) ${ }^{13}$, which consists of 2 aspects, and this scale has 31 items that have previously been tested with a reliability of 0.90 . Intrinsic, example of the item "in general, do you trust the senior people in your organization". Extrinsic, for example the item "does your job have a negative impact on your selfesteem". This scale, after going through the calculation of the item discrimination power, there are 5 items that are lost. The number of items remaining is 25 items with a reliability of 0.948 .

\section{Method of collecting data}

Collecting data in this study using a questionnaire obtained directly from respondents. The questionnaire contains statements from each scale. Furthermore, all variables in this study were measured using the Rating Scale.

The work engagement scale consists of 6 scores ranging from a score of 1 (Almost Never), a score of 2 (Rarely), a score of 3 (Sometimes), a score of 4 (Often), a score of 5 (Very Often), a score of 6 (Always).

The psychological capital scale consists of 6 scores starting with a score of 1 (Strongly Disagree), score 2 (Disagree), score 3 (Somewhat Agree), score 4 (Somewhat Agree), score 5 (Agree), score 6 (Strongly Agree) .
The workplace wellbeing scale consists of 4 scores ranging from a score of 1 (Absolutely Not), a score of 2 (Little), a score of 3 (Moderate), a score of 4 (Very), to a score of 5 (Outstanding).

\section{Data analysis technique}

The data analysis used in this study was multiple regression analysis techniques using SPSS version 21.0.

\section{RESULT}

Based on the research results, it is known that several results include:

\section{Validity and Reliability Test Results}

Validity shows the accuracy of a score (measurement scale). Reliability shows the consistency and stability of a score (measurement scale). In the Psychological Capital variable $\left(\mathrm{X}_{1}\right)$, a Cronbach Alpha score was obtained of 0.922 which indicates the Reliable Psychological Capital variable, the workplace wellbeing variable $\left(\mathrm{X}_{2}\right)$ with a Cronbach Alpha score of 0.948 which indicates the wellbeing variable in the Workplace is Reliable, and the Work Engagement variable (Y) obtained a Cronbach Alpha score of 0.753 which indicates the variable Work Engagement is Reliable.

\section{Normality Test Results}

The normality test aims to assess the distribution of data in a group of data or variables, whether the distribution of the data is normally distributed or not.

Table 1. Normality Test Results

\begin{tabular}{|l|l|l|l|l|l|c|}
\hline Tests of Normality & \multicolumn{9}{|l|}{ Kolmogorov-Smirnov ${ }^{\mathbf{a}}$} & \multicolumn{3}{|l|}{ Shapiro-Wilk } \\
\cline { 2 - 8 } & Statistic & df & Sig. & Statistic & df & Sig. \\
\hline Modal Psikologis & .069 & 134 & $.200^{*}$ & .984 & 134 & .125 \\
\hline Kesejahteraan di Tempat Kerja & .081 & 134 & .031 & .987 & 134 & .241 \\
\hline Keterikatan Kerja & .056 & 134 & $.200^{*}$ & .983 & 134 & .091 \\
\hline
\end{tabular}

Table 1. Shows the significance value of the Psychological Capital and Work Engagement variables of 0.200, greater than 0.05 . So in accordance with the basis of decision making in the Kolmogorov-Smirnov Normality Test above, it can be concluded that the data is normally distributed. Meanwhile, the wellbeing data in the Workplace has a significance value of 0.031 which is smaller than 0.05 . So it can be said that the data is not normally distributed. Thus, the 
Osa Dyahayu Kalmudojati. The influence of psychological capital and workplace well-being on work engagement of bank employees.

assumptions or normality requirements in the regression model have not been fully met.

\section{Linearity Test Results}

Linearity test aims to determine whether or not a data distribution is normal.
This is associated with the $\mathrm{t}$ test and the $\mathrm{F}$ test which assume that the residual value is linear or normal. If this assumption is violated then the statistical test will be invalid.

\begin{tabular}{|l|l|l|l|}
\hline ANOVA Table & Table 2. Linearity Test Results & Sig. \\
\hline Work Engagement * Psychological Capital & \multirow{2}{|c|}{ Between Groups } & (Combined) & 0,000 \\
\cline { 3 - 4 } & & Linearity & 0,000 \\
\cline { 3 - 4 } & & Deviation from Linearity & 0,677 \\
\hline Work Engagement * Workplace Wellbeing & \multirow{2}{*}{ Between Groups } & (Combined) & 0,000 \\
\cline { 3 - 4 } & & Linearity & 0,000 \\
\cline { 3 - 4 } & & Deviation from Linearity & 0,163 \\
\hline
\end{tabular}

Table 2. Shows that the Sig. deviation from linearity in Psychological Capital and Work Engagement of $0.677>$ 0.05 , it can be concluded that there is a linear relationship between Psychological Capital and Work Engagement. Likewise, Sig. deviation from linearity in Workplace Wellbeing and Work Engagement scores
$0.163>0.05$, which can be concluded that there is a linear relationship between Workplace Wellbeing at Work and Work Engagement.

\section{Multiple Linear Regression Analysis}

The following is the output of multiple linear regression analysis:

Table 3. Multiple Linear Regression Analysis Test

\begin{tabular}{|l|l|l|l|l|}
\hline \multicolumn{5}{|l|}{ Model Summary } \\
\hline Model & R & R Square & Adjusted R Square & Std. Error of the Estimate \\
\hline 1 & $.768^{\mathrm{a}}$ & .590 & .584 & 5.36418 \\
\hline \multicolumn{7}{|l}{ a. Predictors: (Constant), Workplace Wellbeing (X2), Psychologycal Capital (X1) } \\
\hline
\end{tabular}

Table 3. Based on the output above, it is known that the R Square value is 0.590 , this means that the simultaneous influence of the $\mathrm{X}_{1}$ and $\mathrm{X}_{2}$ variables on the $\mathrm{Y}$ variable is $59 \%$.

\begin{tabular}{|l|l|l|l|l|l|}
\hline Independent Variable & Regression Coefficient & $\mathbf{t}_{\text {count }}$ & $\mathrm{t}_{\text {table }}$ & Sig. & Conclusion \\
\hline Psychological Capital & 0,471 & 7,315 & 1,978 & 0,000 & Significant \\
\hline Workplace Wellbeing & 0,195 & 5,268 & 1,978 & 0,000 & Significant \\
\hline Constanta $=22,190$ & $\mathrm{R}=0,590$ \\
\hline $\mathrm{F}_{\text {count }}=94,391$ & \\
\hline Sig $=0,000$ &
\end{tabular}

The multiple regression equation based on the results of the regression analysis can be seen as follows:

$Y=22,190+0,471 x_{1}+0,195 x_{2}$

Information:

1. A constant value of 22.190 means that if the variables of Psychological Capital and Workplace Wellbeing are zero, then Work Engagement is 22.190.
2. The beta coefficient value on the Psychological Capital variable is 0.471 , which means that every increase in the Psychological Capital variable $\left(\mathrm{X}_{1}\right)$ by one unit will result in an increase in employee Work Engagement by 0.471 units. On the other hand, a one-unit decrease in the Psychological Capital variable decreases the Work Engagement by 0.471 , assuming the other factors are constant. 
Osa Dyahayu Kalmudojati. The influence of psychological capital and workplace well-being on work engagement of bank employees.

3. The beta coefficient value on the Workplace Wellbeing variable is 0.195 , which means that each one-unit increase in the Workplace Wellbeing variable $\left(\mathrm{X}_{2}\right)$ will result in an increase in employee Work Engagement by 0.195 units. Conversely, a one-unit decrease in the Welfare at Work variable decreases the Work Engagement by 0.195, assuming the other factors are constant.

\section{Hypothesis testing \\ F test}

Table 4. F Test Results

\begin{tabular}{|l|l|l|l|l|l|l|}
\hline \multicolumn{7}{|l|}{ ANOVA $^{\text {a }}$} \\
\hline Model & Sum of Squares & df & Mean Square & F & Sig. \\
\hline \multirow{2}{*}{1} & Regression & 5432.104 & 2 & 2716.052 & 94.391 & $.000^{\mathrm{b}}$ \\
\cline { 2 - 7 } & Residual & 3769.455 & 131 & 28.774 & & \\
\cline { 2 - 7 } & Total & 9201.560 & 133 & & & \\
\hline
\end{tabular}

Table 4. The results of the $\mathrm{F}$ test basically show whether all the independent variables included in the model have a simultaneous influence on the dependent variable. Decision making is made based on the calculated $\mathrm{F}_{\text {count }}$ by looking at the significance value, then comparing it with the predetermined significance level $(5 \%$ or $0.05)$. If the significance of the $p$ value is less than 0.05 , then $\mathrm{H}_{\mathrm{o}}$ is rejected, which means that the independent variable simultaneously affects the dependent variable. From the results of the F test, it was obtained that the $\mathrm{F}_{\text {count }}$ was 94.391 and the $F_{\text {table }}$ value was 3.06. While the significance is 0.000 . Because the significance value is below 0.05 and the $F_{\text {count }}$ value is greater than the $F_{\text {table }}$ value (94.391 > 3.06), then the hypothesis which states "There is a significant positive effect of psychological capital and workplace well-being on work engagement employees" are declared accepted or proven.

\section{DISCUSSION}

\section{The Influence of Psychological Capital on Employee Engagement}

Hypothesis testing on the effect of psychological capital on work attachments to employees in this study resulted in a $t_{\text {count }}$ of 7.315 with a significance level of 0.000 ( $\mathrm{p}<0.05$ ), so from these results it can be concluded that psychological capital has a significant effect on work attachment to employees. Regression analysis results obtained R Square value of 0.504 , which indicates that the variable psychological capital has an influence on work engagement of employees by $50.4 \%$.

The results of the calculation of multiple linear regression analysis with partial testing of the variable Psychological Capital have an influence on work engagement among employees. According to Fransiska, Sari, et al. (2009) ${ }^{19}$ a positive value on the correlation coefficient means that the higher the psychological capital, the higher the work attachment. Conversely, the lower the psychological capital, the lower the work attachment.

There are many benefits of having a work attachment, as stated by Johanes (2016), that employees in a company have a high work engagement, so this will affect the outcome of the company both financially and employee welfare. This may imply that the higher the work engagement, the higher the job satisfaction and organizational commitment. Meanwhile, according to Salanova (in Lin, 2009) ${ }^{20}$ that low work engagement will also be followed by low employee performance, which can even lead to employee boredom.

The results of this study indicate that the psychological capital on work engagement among bank employees has a linear relationship and the level of influence of psychological capital on work engagement is 50\%. According to Schiemann $(2011)^{21}$ there is a mutual commitment to rights, which does not only include attractive wages or benefits, but also 
Osa Dyahayu Kalmudojati. The influence of psychological capital and workplace well-being on work engagement of bank employees.

skills development, or the availability of certain human resources provided by the company, this allows employees to develop.

\section{The Effect of Workplace Wellbeing on Employee Engagement}

The results of further hypothesis analysis show that there is an influence of the wellbeing variable in the workplace on work engagement to employees resulting in a $t_{\text {count }}$ value of 5.268 which is greater than t-table 1.978 and a significance of 0.000 (p $<0.05$ ), so from these results it can be concluded that the wellbeing in workplace has a significant positive effect on work engagement to bank employees. This result is also supported by the coefficient of determination indicated by the $\mathrm{R}$ Square value of 0.423 indicating that $42.3 \%$ of welfare in the workplace contributes to work engagement with bank employees.

The effect of workplace wellbeing on work engagement is $42.3 \%$ because the employee's need for the wellbeing provided at work makes employees feel comfortable at work, so that the influence of wellbeing at work on work engagement to employees is quite large and while $57,7 \%$ is influenced by other factors outside of research. The results of the calculation of multiple linear regression analysis with partial testing of the wellbeing variable in the Workplace have an influence on Work Engagement among employees. These results are in line with Lilita (2013) which states that wellbeing is conceptualized as the process most related to work engagement, and employment plays an important role in work involvement, both as a contribution. Excess workload and management style can affect engagement in work both emotionally and physically.

Based on the results of the analysis in this study, data was obtained that workplace well-being and work engagement to employees had a linear relationship and the level of influence of workplace wellbeing on work engagement to employees was $42.3 \%$. This sense of attachment makes employees enthusiastic about work. This is consistent with research conducted by
Fairhurst (2010), engagement increases company revenue by $57 \%$, increases firm value by $16 \%$, and increases employee wellbeing by $20 \%$.

\section{The Influence of Psychological Capital and Workplace Wellbeing on Work Engagement of Bank Employees}

The results of further hypothesis analysis indicate that there is an influence of the variable psychological capital and workplace wellbeing on work engagement with employees, after statistical analysis, the significance coefficient value is 0.000 ( $\mathrm{p}<$ 0.05 ) with an R Square value of 0.590 . This shows that the hypothesis is accepted, namely that there is an effect of psychological capital and workplace wellbeing together on work engagement to bank employees by $59 \%$, while $41 \%$ is influenced by other factors outside of the research.

An interesting result is seen when we consider the effect of each variable on employee work engagement. Psychological capital and well-being in the workplace have an influence on work engagement to employees. The average participant's work engagement variable is quite high. Albrecht (2010) suggests that work engagement is a state of positive and energized motivation related to work and the genuine desire of employees to contribute to work roles and organizational success. It can be said that employees who have a high level of work engagement will show their best performance at work (Bakker and Leiter, 2010) ${ }^{22}$. Robertson (2007) also says that employees who are tied to their work will show enthusiasm, a real passion about their work and for the organization. In addition, employees will also enjoy the work they do and are willing to provide all assistance to be able to succeed in the organization where they work.

The average psychological capital variable of participants is quite high. This shows that employees with high psychological capital will be more flexible and adaptable to do several things in 
Osa Dyahayu Kalmudojati. The influence of psychological capital and workplace well-being on work engagement of bank employees.

meeting the work demands of employees (Avey, Luthans and Palmer, 2010). They are motivated to pursue their goals and as a result they will get satisfaction, because it can create a close work attachment (Luthans and Youssef, 2007) ${ }^{18}$.

The average wellbeing variable in the participants' workplace was not very high. Dienar, Lucas and Oishi $(2005)^{23}$ explain that well-being is an individual's evaluation of his life, including cognitive assessments of life satisfaction and affective assessments of his emotions, such as what ordinary people call happiness, tranquility, and life satisfaction. Wright and Bonett $(2007)^{24}$ also explain that when a person assesses the work environment as attractive, fun and full of challenges, it can be said that he feels happy and shows optimal performance. Individuals will be able to control themselves and face various events in life well and vice versa, individuals with low welfare will look down on their lives and perceive the events that occur as unpleasant so that unpleasant emotions appear such as anxiety at work, depression and anger (Diener and Lucas, 1999) ${ }^{25}$.

\section{CONCLUSIONS AND SUGGESTIONS Conclusion}

The psychological capital of a person and the wellbeing felt by employees in the workplace or environment has an influence on the employee's sense of engagement in carrying out work activities. A positive attitude and psychological readiness in employees are one of the driving factors for the emergence of work engagement to employees in addition to the sense of well-being they get from the work environment. This finding further confirms the many findings of previous studies, particularly in the field of Industrial and Organizational Psychology. The existence of the influence of workplace wellbeing in the place or work environment also shows that this variable is dynamic in studies related to work engagement to employees. Work engagement can also be involved in future studies with different problems and participants.

\section{Suggestion}

There are several suggestions that can be put forward regarding the results of this study. First, expanding the demographic coverage of the participants to even larger areas. Second, increasing the number of respondents so that the research results can be even better. Third, re-examine what variables can have a major influence on work engagement to employees.

\section{Acknowledgement: None}

\section{Conflict of Interest: None}

\section{Source of Funding: None}

\section{REFERENCES}

1. Robbins, S. (2006). Perilaku organisasi (Edisi ke-10). Jakarta: Indeks.

2. Supomo. (2011). Kompetensi banker dalam industri perbankan di Indonesia. Diunduh tanggal $19 \quad$ Oktober 2011. http://www.lppi.or.id/index.php/module /Editorial/id/kompetensi-bankir-dalamindustri perbankan-di-indonesia.

3. Schaufeli, W. (2006). Utrecht work engagement scale preliminary manual. Thesis (Unpublished). Occupational Health Psychology Unit Utrecht University.

4. Watson, W. T. (2017). Global benefits attitudes survey. Published at November $17^{\text {th }}$ 2017. https://www.willistowerswatson.com/en/insi ghts/2017/11/2017-global-benefits-attitudessurvey.

5. BSRI. (2011). National clearing system turnover a $86.5 \%$ of total transactions nationwide. Published at Oktober $19^{\text {th }} 2011$. http://www.bi.go.id/web/id/Perbankan/Ikhti sar+Perbankan/Lembaga+Perbankan/.

6. Schaufeli, W., \& Bakker, A. (2010). The conceptualization and measurement of work engagement. in A.B. Bakker \& M.P. Leiter (Eds.). work engagement a handbook of essential theory and research. New York Psycho. 10-24.

7. Attridge, M. (2009). Measuring and managing employee work engagement: a review of the research and business 
Osa Dyahayu Kalmudojati. The influence of psychological capital and workplace well-being on work engagement of bank employees.

literature. Journal of Workplace Behavior Health. 24, 383-398.

8. Simbula, S., \& Guglemi, M. (2013). I am engaged, I feel good, and I go tehe extramile: reciprocal relationship between work engagement and consequences. Journal of Work And Organizational Psychology. 29, 117-125.

9. Handayani, D. A. (2016). Hubungan antara work engagement dengan organizational citizenship behavior pada karyawan kontrak. Jurnal Ilmiah Psikologi. 9(1). 5868.

10. Luthans, F., \& Youssef, C. M. (2007). Emerging positive organizational behavior. Journal of Management, 22(3), 321-349.

11. Mujiasih., \& Ratnaningsih, I. Z. (2012). Meningkatkan work engagement melalui gaya kepemimpinan transformasional dan budaya organisasi. Jurnal Psikologi Industri dan Organisasi. 1(2). 161-168.

12. Page, K. M. (2005). Subjective wellbeing in the workplace. Thesis (Tidak Diterbitkan). School of Psychology Faculty of Health and Behavioural Sciences Dreakin University.

13. Schmidt, F. (2004). Workplace well-being in the public sector - a review of the literature and the road ahead. Treasury Board of Canada Secretariat.

14. Sari, D. W. (2015). Hubungan antara workplace well-being dengan employee engagement pada staff tata usaha Universitas Kristen Satya Wacana Salatiga. Skripsi (Tidak Diterbitkan). Universitas Kristen Satya Wacana Fakultas Psikologi.

15. Kurniadewi, E. (2016). Psychological capital dan workplace well-being sebagai predictor bagi employee engagement. Jurnal Psikologi Integratif. 4(2). 95-112.

16. Schaufeli, W., \& Bakker, A. (2004). Job demans, job resources, and their relationship with burnout and engagement: a multisample study. Journal of Organizational Behavior, 25(3), 239-315.
17. Luthans, F., Youssef, M. C., \& Avolio, B. J. (2007). Psychological capital: developing the human competitive edge. New York: Oxford University Press Inc.

18. Fransiska, Y. M., Sari, M. T., Purwaningrum, E. K., \& Ramadhan, Y. A. (2009). Pengaruh modal psikologis terhadap keterikatan kerja pada karyawan di PT. Grand Mandiri Utama. Jurnal Psikologi. 1(2). 22-32.

19. Lin, C. P. (2009). Modeling corporate citizenship, organizational trust, and work engagement based on attachment theory. Journal of Business Ethnics. Doi: 10.1007/s10551-009-0279-6.

20. Schiemann, A. W. (2011). Alignment capability engagement. Jakarta: PPM Management.

21. Bakker, A. B., \& Leiter, M. P. (2010). Work engagement: A handbook of essential theory and research. New YorK: Psychology Press.

22. Dienar, E., Lucas, R. E., \& Oishi, S. (2005). Subjective well-being: The science of happinesss and life satisfaction. The handbook of positive psychology. New York: Oxford University Press.

23. Wright, T. A., \& Bonett, D. G. (2007). Job satisfaction and psychological well-being as nonadditive predictors of workplace turnover. Journal of Management, 33(2), 141-160.

24. Diener, E., \& Lucas, E. (1999). Personality and subjective well-being. Well-being: The foundations of hedonic psychology. New York: Russel Sage.

How to cite this article: Kalmudojati OD. The influence of psychological capital and workplace well-being on work engagement of bank employees. International Journal of Research and Review. 2021; 8(5): 449-457. DOI: https://doi.org/10.52403/ijrr.20210555 